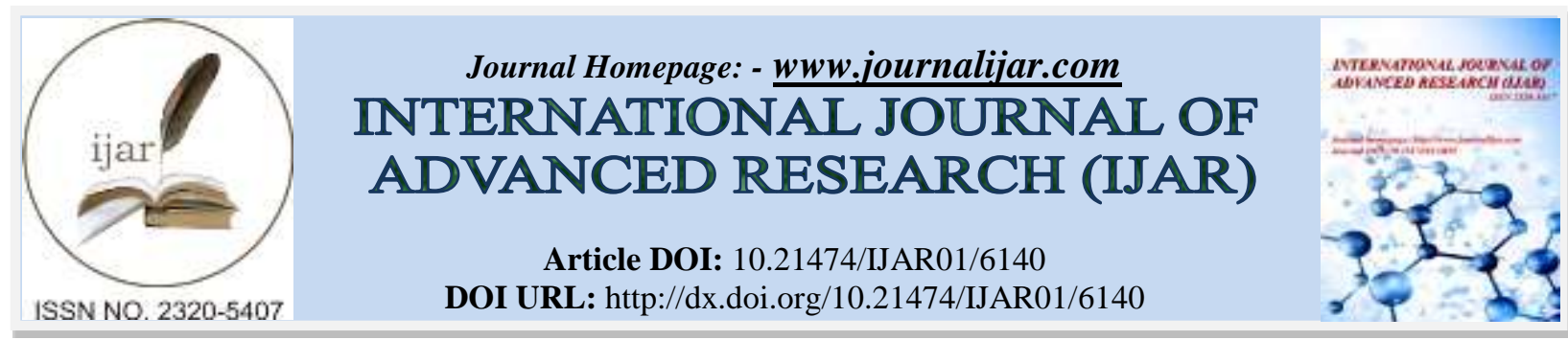

RESEARCH ARTICLE

\title{
LEVELS AND BARRIERS OF GLYCEMIC CONTROL AND SELF-MANAGEMENT AMONG DIABETIC PATIENTS IN PRIMARY HEALTH CARE IN JEDDAH: A CROSS-SECTIONAL STUDY.
}

Emad A. Bakhsh and Sulafa T. Al Qutub.

Primary Health care, Ministry of Health, Jeddah, Saudi Arabia.

\section{Manuscript Info}

Manuscript History

Received: 23 October 2017

Final Accepted: 25 November 2017

Published: December 2017

Key words:-

Type 2 diabetes; Glycemic control; Selfmanagement; Primary care; Saudi Arabia.

\section{Abstract}

Objectives: To assess the level of and factors affecting glycemic control, quality of diabetes self-management, and the impact of selfmanagement on glycemic control among patients with type 2 diabetes (T2D) at the primary healthcare(PHC) level.

Methods: This was a cross-sectional study involving adult patients with T2D visiting PHC centers in Jeddah, Saudi Arabia. Stratified twostage clustered sampling was used to select participants from 10 PHC centers. Optimal glycemic control was defined as a glycated hemoglobin (HbAlc) level $<7 \%$ on the last ( $\leq 3$ months from the start of the study) HbA1c reading. Diabetes self-management was assessed using the Diabetes Self-Management Scale (DSMS), comprising 7 subscales and calculated as a score (range $=60-240$ ).

Results: Diabetes control was expressed as mean (standard deviation [SD]) HbA1c of $8.23 \%$ (1.76), and was optimal in $25.6 \%(95 \%$ confidence interval $[\mathrm{CI}]=21.2 \%, 30.5 \%$ ) of the 359 patients. Reliability testing of the DSMS showed a Cronbach's alpha of 0.960. Mean (SD) DSMS score for the total study population was 150.30 (30.61; range $=60-238$ ). There was a weak but significant negative correlation between HbA1c (\%) and raw DSMS score $(\mathrm{r}=0.265$; $\mathrm{B}=0.016$; $\mathrm{p}=0.001)$. Patients who had optimal glycemic control had higher DSMS (mean $[\mathrm{SD}]=167.13$ [29.82]) compared to those with suboptimal glycemic control (mean [SD]=145.72 [29.34]; p=0.001). In univariate binary logistic regression, predictors of optimal glycemic control included age $\geq 60$ years (odds ratio $[\mathrm{OR}]=0.28 ; \mathrm{p}=0.030$ ); high educational level $(\mathrm{OR}=3.80 ; \mathrm{p}=0.038)$; diabetes duration $6-10$ years $(\mathrm{OR}=0.51 ; \mathrm{p}=0.037)$; treatment regimen comprising insulin alone $(\mathrm{OR}=0.18 ; \mathrm{p}=0.011)$ or combined with oral antidiabetic drugs $(\mathrm{OR}=0.19 ; \mathrm{p}=0.009) ;$ and excellent quality of self-management (DSMS $\geq 170 / 240 ;$ OR $=8.18 ; \mathrm{p}=0.003$ ).

Conclusion: Optimal glycemic control was achieved in approximately $25 \%$ of patients. The level of glycemia is significantly associated with the quality of self-management. Old age, low educational level, and treatment regimen containing insulin are the most significant factors associated with poor glycemic control.

Copy Right, IJAR, 2017,. All rights reserved. 


\section{Introduction:-}

Type 2 diabetes mellitus (T2DM) represents a significant public health issue in Saudi Arabia, with an estimated prevalence of over $30 \%$ of the population, rankings the second most common disease in the Middle East and seventh most common worldwide $(1,2)$. Based on statistics provided by the Saudi Ministry of Health (MOH), diabetes accounts for approximately $14 \%$ of annual Saudi healthcare expenses (1). Furthermore, patients with T2DMrequire a tenfold greater out-of-pocket health expenditure than those without diabetes (3). This economic burden is coupled with high mortality and morbidity, including micro- and macrovascular complications, poor general health, and impaired quality of life $(1,4-7)$.

The particular aspects pertaining to T2DM management, including lifestyle modification, long-term medication use, regular clinical and laboratory follow-ups, and screening and prevention of complications, may be demanding for both the healthcare system and the patient (8). Over the last two decades, several strategies have been implemented to manage diabetes and prediabetes in Saudi Arabia, including community-based awareness and screening programs, the improvement of management systems and protocols in public healthcare and specialized diabetes centers. Despite these measures, several gaps in the healthcare provision remain with poorT2DM awareness, late diagnosis, and inadequate follow-up; these gaps lead to suboptimal glycemic control (1,9-12). Local studies report that only $26 \%$ to $33 \%$ of patients with T2DM achieve the recommended levels of glycated hemoglobin (HbA1c) (13-16). Achieving optimal glycemic control is a key factor in the prevention against diabetes micro- and macrovascular complications $(17,18)$.

Several factors have been associated with suboptimal glycemic control. These include poor patient literacy, awareness and understanding of the disease, poor compliance with treatment or dietary recommendations, limited physical activity, intensive treatment regimens, treatmentcosts, longstanding diabetes and comorbidities such as obesity and depression (13-15,19-24). Sociodemographic factors, such as older age, low educational level, low economic status, and absence of social support may also constitute direct or indirect barriers to diabetes care and optimal glycemic control $(16,25,26)$.

A further factor associated with the level of glycemic control that has gained remarkable interest in recent years is the quality of self-management or self-care $(1,15,27)$. The paradigm of self-management evolved from a patient education-based model of empowerment, targeting patients with chronic diseases. It is now regarded as an efficient strategy with long-term benefits for both the patient and the healthcare system, associating reduced health expenditure with reduced hospitalization rates and length of stay and reduced medication usage $(28,29)$. More specifically, diabetes self-management (DSM) involves a multi-pronged approach, including adherence to treatment, dietary and lifestyle regimens; foot care; regular blood sugar monitoring; and improving self-efficacy and selfconfidence in self-management (30-32). Enhancing DSM has been shown to improve both treatment adherence and glycemic control (15,33-35). Different approaches have been developed, and a range of education programs are available; furthermore, different scales are available to measure the overall quality and specific components of DSM (36-40).

This study aimed to assess the level of glycemic control and its associated factors among diabetic patients at primary healthcare centers and to examine the quality of diabetes self-management and its impact on glycemic control.

\section{Materials and Methods:-}

\section{Design and setting}

A cross-sectional study was conducted involving patients with T2DM attending the PHC center in Jeddah, Saudi Arabia, between 1 November 2016 and 28 February 2017. The study protocol was approved by the research committee of the Ministry of Health directorate of health affairs in Jeddah. A total of 46 PHC centers are situated in Jeddah, divided into 5 sectors: Northeastern, Northwestern, Center, Southeastern and Southwestern sectors. Each sector includes 7 to 13 PHC centers.

\section{Study population}

The number of Saudi patients with T2DM attending primary healthcare centers in Jeddah was estimated at 34,452 in 2016, according to reports issued by the Health Information Center, Public Health Administration, Jeddah. The following study inclusion criteria applied: age $\geq 20$ years, Saudi nationality, diagnosis of T2D, and a minimum 1-year history of regular follow-up at one of the participating PHC centers. 


\section{Sampling}

Sample size was calculated to estimate an assumed proportion of $26.2 \%$ (13) of participants with optimal glycemic control (HbA1c<7\%) among a total of 34,452 patients with T2DM attending the PHC centers in Jeddah. Considering a 5\% type I error and 95\% confidence interval (CI), the sample size was calculated as $\mathrm{N}=294$, which was increased to 350 to compensate for potential dropouts or those with incomplete data.

Stratified two-stage clustered sampling was used to include the participants from a total of 10 PHC centers. Two PHC centers were selected from each of the 5 sectors using an electronic random digit generator. Patients were recruited during their regular attendance at the clinic for patients with diabetes. Out of each participating center, 3540 eligible and consenting patients were enrolled in the study using a systemic random sampling method (every third patient) until the target number of participants was achieved.

\section{Study tools}

The level of glycemic control was determined using the last HbA1c reading (taken within the preceding 3 months) retrieved from patient's medical record, in addition to other relevant clinical data, including duration of diabetes (expressed in number of years) and treatment regimen when not reported by the patient. Optimal glycemic control was defined as a HbA1c level <7\%, as recommended by the American Diabetes Association (ADA) $(8,41)$.

Diabetes self-management was assessed using the Diabetes Self-Management Scale (DSMS), based on and adapted from the ADA standards of care and the conceptual model of performance in activities related to diabetes self-care $(8,39)$. The scale consists of a semi-structured, validated questionnaire including60 items divided into 7 subscales, each assessing one of the following dimensions: healthy eating ( 15 items); being active (6 items); monitoring blood glucose (5 items), taking medication (6 items), foot care ( 7 items); problem solving ( 8 items and reducing risks (13 items). Each item is a 4-point Likert-type scale assessing agreement level (1=strongly disagree; $2=$ moderately disagree; $3=$ moderately agree; $4=$ =strongly agree) regarding the self-care activity stated for each item.

\section{Statistical Methods}

Statistical analysis was performed using SPSS, version 21 (IBM SPSS Statistics for Windows, Armonk, NY: IBM Corp. 2012). Reliability of the DSMS tool was tested by calculating Cronbach's alpha for overall DSMS as well as for each subscale separately. Descriptive statistics were performed to examine demographic and clinical characteristics. The level of glycemic control was calculated as the percentage of patients with optimal HbAlc levels and the result is presented as a percentage $(95 \% \mathrm{CI})$. The level of self-management was analyzed by calculating total and subscale DSMS scores. The total DSMS score (range=60-240) was calculated by adding the scores of all of the 60 questionnaire items.

For subscales, two types of scores were calculated: raw and scaled scores. Raw scores were calculated by adding the scores of the respective items within each subscale. Scaled scores (range $=1-4)$ were calculated by dividing the subscale raw scores by the respective number of items. All scores were analyzed as continuous variables and compared using independent t-tests for binomial variables and one-way ANOVA for multinomial variables. The level of overall self-management was assessed according to 4 categories: poor (DSMS <133), moderate (DSMS 133 to $<150$ ), good (DSMS 150 to $<170$ ), and excellent (DSMS $\geq 170$ ). These cut-off values correspond to the $25^{\text {th }}, 50^{\text {th }}$, and $75^{\text {th }}$ centiles. The correlation of glycemic control with self-management was analyzed using three different methods: 1) comparison of DSMS total and subscale scores between the group of participants with optimal glycemic control and the group without optimal glycemic control, using independent t-tests, 2) linear regression using the HbA1c level as the dependent variable and DSMS total and subscale scores as the independent variables, and 3) comparison of HbAlc values among the different levels of DSMS using one-way ANOVA. Univariate and multivariate binary logistic regression analysis was performed to analyze predictors of glycemic control using glycemic level (optimal versus non-optimal) as the dependent variable; results are presented as odds ratios (OR) with $95 \%$ CI. A p-value $<0.05$ was fixed to reject the null hypothesis.

\section{Results:-}

Questionnaire reliability

Analysis of overall DSMS questionnaire reliability showed a Cronbach's alpha value of 0.960 . Reliability of the different questionnaire subscales ranged between 0.845 and 0.928 for "problem solving" and "being active", respectively (Table 1). 


\section{Demographic and clinical characteristics}

Out of a total of 359 participants, 50.1\% were female, 34.5\% were aged 40-49 years, 55.2\% were employed, and $33.7 \%$ were highly educated (above university level, university+). In $40.1 \%$ of patients, diabetes duration was $>10$ years. Patient treatment regimens were as follows: combined oral antidiabetic drugs (OADD) and insulin (39.8\%), OADD alone (33.4\%), insulin alone (23.4\%)and no medication (3.1\%). Diabetes control was expressed as mean (SD) HbA1c=8.23 (1.76\%); optimal control $(<7 \%)$ was observed in $25.6 \%$ of patients $(95 \% \mathrm{CI}=21.2 \%, 30.5 \%)$ (Table 2).

\section{Diabetes self-management}

The mean (SD) raw DSMS score for the total study population was 150.30 (30.61) [range=60-238]. Adjusted scores of different subscales ranged between 2.12/4 and 2.63/4 (Table 3).

\section{Correlation of self-management with glycemic control}

There was a weak but significant negative correlation between HbA1c (\%) and raw DSMS ( $\mathrm{r}=0.265$; $\mathrm{B}=0.016$; $\mathrm{p}=0.001$ ) (Figure 1). Patients with optimal (HbA1c<7\%) glycemic control had a higher DSMS (mean [SD]=167.13 [29.82]) than those with suboptimal glycemic control (mean [SD]=145.72 [29.34]), the difference for which was statistically significant $(\mathrm{p}=0.001$; independent t-test; Figure 2). Higher DMS subscale scores were found in patients with optimal glycemic control rather than in those with suboptimal glycemic control (Table 3). Furthermore, analysis showed a weak but statistically significant negative linear correlation between HbA1c and each of the DSMS subscales (Supplemental Figure 1).

\section{Factors and predictors of self-management}

Higher DSMS was associated with high educational level $(p=0.001)$ and employment status $(p=0.037)$. No correlation was found with age $(p=0.259)$, years of diabetes $(p=0.652)$, or treatment regimen $(p=0.365)(T a b l e ~ 4)$. Predictors of DSMS were educational level $(B=6.59$ [95\% CI=3.45, 9.72]; $\mathrm{p}=0.001)$ and HbA1c level $(\mathrm{B}=-3.59$ $[95 \% \mathrm{CI}=-5.58,-1.62] ; \mathrm{p}=0.001)$; while professional status was not a significant predictor and was excluded from the stepwise regression model $(\mathrm{p}=0.684)$. Further, patients of a relatively younger age $(20-39$ years $)$ had higher scores in the following DSMS subscales: being active, monitoring blood glucose, and problem solving. Those with a high educational level had higher scores in all DSMS subscales, except in "taking medication" where the difference was not statistically significant. Patients administered insulin alone or in combination with OADD had higher scores in the following subscales: monitoring BG, taking medication, and problem solving (Table 5).

\section{Predictors of optimal glycemic control}

In univariate binary logistic regression, predictors of optimal glycemic control included age $\geq 60$ years $(\mathrm{OR}=0.28$; $\mathrm{p}=0.030)$, university+ educational level $(\mathrm{OR}=3.80 ; \mathrm{p}=0.038)$, diabetes duration of $6-10$ years $(\mathrm{OR}=0.51 ; \mathrm{p}=0.037)$, treatment with insulin alone $(\mathrm{OR}=0.18 ; \mathrm{p}=0.011)$ or in combination with $\mathrm{OADD}(\mathrm{OR}=0.19 ; \mathrm{p}=0.009)$, and excellent glycemic self-management $(\mathrm{DSMS} \geq 170 / 240 ; \mathrm{OR}=8.18 ; \mathrm{p}=0.003$ ). Furthermore, all DSMS subscale scores were significant predictors of optimal glycemic control. None of the above predictors were significant in the three different multivariate models. Multivariate model 1 included all significant predictors in the univariate model and is presented in Table 6 with the univariate model. Multivariate model 2 included educational level, treatment regimen, DSMS level (poor, moderate, good, excellent), and DSMS subscales. Multivariate model 3 included treatment regimen, DSMS level, and DSMS subscales. Multivariate model 2 and 3 are not presented here.

\section{Discussion:-}

This study found low levels of glycemic control among patients with T2DM in PHC, with optimal glycemic control achieved in only $25 \%$ of patients. Old age, low educational level, and treatment regimens including insulin were the most significant demographic and clinical factors associated with poor glycemic control. Furthermore, this study showed a significant correlation between glycemic control and quality of self-management, as demonstrated by the negative linear correlation between DSMS scores and HbA1c levels. This correlation was further corroborated by the finding that a DSMSscore $\geq 170$ was a significant predictor of optimal glycemic control in univariate binary logistic regression. Furthermore, all DSMS subscales showed a negative linear correlation with HbA1c levels and were significant predictors of optimal glycemic control. These findings highlight the need to identify patient-related obstacles to glycemic control, notably poor self-management, in addition to gaps in clinical practice to improve diabetes management strategies in PHC centers. 
A number of local and international studies investigated glycemic control among diabetic patients, reporting a generally suboptimal glycemic control. Among studies in Saudi Arabia, 26.2\% of patients with T2DM in Al Madinah (13) and 26.0\% of patients in Jizan (15), achieved the recommended HbA1c levels. This finding is consistent with our findings. In Riyadh city, Al-Rasheedi et al. reported a higher rate of optimal glycemic control (32.3\%) (14). Alsulaiman et al. reported a lower level of glycemic control, with only 59.3\% of participants achieving $\mathrm{HbA} 1 \mathrm{c}<8 \%(20)$. Although the level of glycemic control is not satisfactory, type I diabetes is associated with even lower levels of control. Aljabri reported that only $9.5 \%$ of patients with type I diabetes in Jeddah achieved glycemic control (19), while another study found that $10.5 \%$ of participants achieved glycemic control (13). Worldwide, comparable findings have been reported in both developed and developing countries, with up to38.7\% of patients achieving optimal glycemic control, with some variation between different populations and settings $(22,24,26,42-46)$.

Consistent with our findings, a range of demographic and clinical factors affect glycemic control, with varying levels of significance. Demographic factors include old age, sex, marital status, and low economic and educational level $(16,23,25,26,47)$. Clinical factors include long diabetes duration, low levels of physical activity, intensive treatment regimen, and comorbidities such as obesity and depression $(16,25,26)$. Further obstacles to glycemic control have been reported, including treatment costs, absence of social support, poor patient literacy level, awareness or understanding of the disease, and negative attitudes towards diabetes. These are in addition to factors pertaining to self-management, particularly practices in medication compliance, blood glucose testing, and noncompliance with dietary recommendations $(13-15,19-24,43,48)$.

The multitude of factors affecting glycemic control supports the importance of developing a personalized approach to the promotion of self-management and patient education. This approach relies on the accurate evaluation of the gaps and needs in the education strategies aimed at patients at the individual level. This could be achieved by promoting the systematic and regular use of reliable tools, such as the DSMS, among healthcare professionals dealing with patients with T2DM. Reliability testing of the DSMS and its subscales in the study population has been reported as good-to-excellent using Cronbach's alpha scores (49). Previous research analyzing the content validity of the DSMS showed acceptable scores in all subscales, in addition to good inter-rater agreement (39). This questionnaire was designed and refined to reflect the ADA standard of diabetes care (8).

In the present study, improved self-management, indicated by the DSMS score, was associated with high educational level and employed professional status. DSMS subscales were affected by other demographic and clinical factors, including age, marital status, years of diabetes, and treatment regimens, particularly the inclusion of insulin. Remarkably, patients administered insulin alone had the highest scores in dimensions pertaining to monitoring blood glucose, medication compliance, and problem solving. Conversely, patients administered combined insulin and oral antidiabetic drugs, generally associated with advanced diabetes, achieved the lowest scores in "being active" and relatively low scores in the monitoring blood glucose. Previous studies have reported that diabetes self-management, assessed using the DSMS, was associated with age, general health status, patient's knowledge about the disease, and self-efficacy, as well as both type and duration of diabetes (39). Obstacles to selfmanagement reported by patients include difficulties in adhering to dietary rules, physical exercise, and blood glucose monitoring (50). This is consistent with the findings of the present study, where "being active", "monitoring blood glucose", and "healthy eating" subscales were associated with the lowest subscale scores; however, these subscales correlated strongly with HbA1c levels, compared to the other DSMS subscales. These observations suggest that some aspects of self-management are challenging for patients and that education programs should focus on these aspects to efficiently improve glycemic control.

Behavioral interventions, referred to as self-management supportive interventions, aim to promote behavior change among diabetic patients and result in a decline in HbA1c. They are designed to provide patients with skills and techniques to enhance positive change in behaviors and improve performance in diabetes management. Conversely, behavioral interventions werenecessary, regardless of the level of patient's coping with the disease and perceived need for education $(21,51,52)$. However, the efficacy of these interventions was greater when implemented by healthcare professionals, such as physicians and dietitians, with more considerable effects on HbA1c levels among patients with high baseline HbA1c levels (40). 
This study found a low level of glycemic control among patients with T2DM attending PHC centers, with optimal glycemic control achieved in $25 \%$ of patients. Old age, low educational level, and treatment regimens including insulin were the most significant demographic and clinical factors associated with poor glycemic control.

The quality of diabetes self-management and relevant diabetes self-management dimensions suchas monitoring blood glucose, medication adherence and problem-solving aptitude are significant factors and predictors of glycemic control. Diabetes self-management should be promoted by a systematic and methodic evaluation of gaps and obstacles in the delivery of primary healthcare and diabetes education and by the implementation of targeted behavioral interventions to improve performance in diabetes management.

The range of obstacles to glycemic control and the variability in glycemic control between individuals underscore the importance of a personalized approach to education and behavioral interventions

Table 1:- Reliability testing of different questionnaire sub-scales

\begin{tabular}{|l|l|l|}
\hline Questionnaire subscale & No. of items & Cronbach's alpha \\
\hline Diabetes Self-Management Scale (DSMS) & 60 & 0.960 \\
\hline DSMS Subscales & & \\
\hline Healthy eating & 15 & 0.913 \\
\hline Being active & 6 & 0.928 \\
\hline Monitoring blood glucose & 5 & 0.860 \\
\hline Taking medication & 6 & 0.863 \\
\hline Foot care & 7 & 0.905 \\
\hline Problem solving & 8 & 0.845 \\
\hline Reducing risk & 13 & 0.912 \\
\hline
\end{tabular}

Table 2:- Demographic and clinical characteristics (N=359)

\begin{tabular}{|c|c|c|c|}
\hline Parameter & Category & Frequency & Percentage \\
\hline \multicolumn{4}{|l|}{ Demographic data } \\
\hline \multirow[t]{2}{*}{ Sex } & Male & 179 & 49.9 \\
\hline & Female & 180 & 50.1 \\
\hline \multirow[t]{5}{*}{ Age (years) } & $20-29$ & 41 & 11.4 \\
\hline & $30-39$ & 77 & 21.4 \\
\hline & $40-49$ & 124 & 34.5 \\
\hline & $50-59$ & 78 & 21.7 \\
\hline & $\geq 60$ & 39 & 10.9 \\
\hline \multirow[t]{2}{*}{ Marital status } & Married & 235 & 65.5 \\
\hline & Not married & 123 & 34.8 \\
\hline \multirow[t]{5}{*}{ Educational level } & Not educated & 27 & 7.5 \\
\hline & Primary & 22 & 6.1 \\
\hline & Middle-school & 54 & 15.0 \\
\hline & Secondary & 129 & 35.9 \\
\hline & University+ & 121 & 33.7 \\
\hline \multirow[t]{2}{*}{ Professional status } & Employed & 198 & 55.2 \\
\hline & Not employed & 158 & 44.0 \\
\hline \multicolumn{4}{|l|}{ Clinical data } \\
\hline \multirow[t]{4}{*}{ Years of diabetes } & $1-5$ & 75 & 20.9 \\
\hline & $6-10$ & 139 & 38.7 \\
\hline & $11-20$ & 110 & 30.6 \\
\hline & $>20$ & 34 & 9.5 \\
\hline \multirow[t]{4}{*}{ Treatment regimen } & OADD & 120 & 33.4 \\
\hline & OADD + insulin & 143 & 39.8 \\
\hline & Insulin alone & 84 & 23.4 \\
\hline & None & 11 & 3.1 \\
\hline HbA1c (\%) & Mean, SD (range $=5.50 ; 16.00)$ & 8.23 & 1.76 \\
\hline
\end{tabular}




\begin{tabular}{|l|l|l|l|}
\hline Glycemic control (HbA1c) & Optimal $(<7 \%)$ & 92 & 25.6 \\
\cline { 2 - 4 } & Non-optimal $(\geq 7 \%)$ & 266 & 74.1 \\
\hline
\end{tabular}

HbA1c: glycated hemoglobin A1c; OADD: oral antidiabetic drug; SD: Standard deviation; Due to missing data, some values do not add up to the total number $(\mathrm{N}=359)$.

Table 3:- Assessment of diabetes self-managementand its correlation with glycemic control

\begin{tabular}{|c|c|c|c|c|c|c|c|}
\hline \multirow[t]{2}{*}{$\begin{array}{l}\text { Self-management } \\
\text { parameter }\end{array}$} & \multicolumn{2}{|c|}{ Total $(\mathrm{N}=359)$} & \multicolumn{2}{|c|}{$\begin{array}{l}\text { Optimal glycemic } \\
\text { control }(\mathrm{N}=92)\end{array}$} & \multicolumn{2}{|c|}{$\begin{array}{l}\text { Non-optimal glycemic } \\
\text { control }(N=266)\end{array}$} & \multirow[t]{2}{*}{ p-value } \\
\hline & Mean & SD & Mean & SD & Mean & SD & \\
\hline DSMS score (raw) & 150.30 & 30.61 & 167.13 & 20.82 & 145.72 & 29.34 & $<.001 *$ \\
\hline \multicolumn{8}{|l|}{ DSMS Subscales } \\
\hline Healthy eating ${ }^{*}$ & 2.47 & 0.62 & 2.71 & 0.71 & 2.38 & 0.57 & $.000 *$ \\
\hline Being active & 2.12 & 0.83 & 2.39 & 0.86 & 2.02 & 0.80 & $.000^{*}$ \\
\hline Monitoring $\mathrm{BG}^{*}$ & 2.19 & 0.77 & 2.40 & 0.77 & 2.12 & 0.76 & $.003 *$ \\
\hline Taking medication & 2.57 & 0.74 & 2.78 & 0.76 & 2.51 & 0.73 & $.020 *$ \\
\hline Foot care & 2.58 & 0.76 & 2.79 & 0.76 & 2.51 & 0.75 & $.002 *$ \\
\hline Problem solving ${ }^{*}$ & 2.57 & 0.67 & 2.71 & 0.66 & 2.52 & 0.67 & $.017 *$ \\
\hline Reducing risk & 2.63 & 0.64 & 2.77 & 0.60 & 2.58 & 0.65 & $.011 *$ \\
\hline $\begin{array}{l}\begin{array}{l}\text { Level of } \\
\text { management } \\
\text { score) }\end{array} \\
\text { (DSMS }\end{array}$ & Freq. & $\%$ & Freq. & $\%$ & Freq. & $\%$ & \\
\hline Poor $(<133)$ & 64 & 17.8 & 5 & 9.4 & 56 & 28.4 & \multirow[t]{4}{*}{$.000^{*}$} \\
\hline Moderate $(133-150)$ & 65 & 18.1 & 11 & 20.8 & 50 & 25.4 & \\
\hline Good $(150-170)$ & 61 & 17.0 & 10 & 18.9 & 54 & 27.4 & \\
\hline Excellent $(\geq 170)$ & 61 & 17.0 & 27 & 50.9 & 37 & 18.8 & \\
\hline
\end{tabular}

BG: blood glucose; DSMS: Diabetes Self-Management Scale; SD: standard deviation; †Adjusted scores were used, corresponding to raw scores divided by the number of items in each respective subscale; * statistically significant result $(\mathrm{p}<0.05)$

Table 4:- Demographic and clinical factors associated with diabetes self-management

\begin{tabular}{|c|c|c|c|c|}
\hline \multirow[t]{2}{*}{ Factor } & \multirow[t]{2}{*}{ Category } & \multicolumn{2}{|l|}{ DSMS } & \multirow[t]{2}{*}{ p-value } \\
\hline & & Mean & SD & \\
\hline \multirow[t]{2}{*}{ Sex } & Male & 148.34 & 32.53 & \multirow[t]{2}{*}{.307} \\
\hline & Female & 152.30 & 28.50 & \\
\hline \multirow[t]{5}{*}{ Age (years) } & $20-29$ & 154.79 & 35.47 & \multirow[t]{5}{*}{.295} \\
\hline & $30-39$ & 156.35 & 34.13 & \\
\hline & $40-49$ & 147.47 & 27.40 & \\
\hline & $50-59$ & 150.22 & 28.97 & \\
\hline & $\geq 60$ & 142.39 & 31.34 & \\
\hline \multirow[t]{2}{*}{ Marital status } & Married & 149.08 & 30.03 & \multirow[t]{2}{*}{.364} \\
\hline & Not married & 152.82 & 31.94 & \\
\hline \multirow[t]{5}{*}{ Educational level } & No education & 125.93 & 31.28 & \multirow[t]{5}{*}{$.000 *$} \\
\hline & Primary & 145.71 & 18.32 & \\
\hline & Middle-school & 138.83 & 30.81 & \\
\hline & Secondary & 149.54 & 29.08 & \\
\hline & University+ & 158.94 & 30.25 & \\
\hline \multirow[t]{2}{*}{ Professional status } & Employed & 153.25 & 29.36 & \multirow[t]{2}{*}{$.037 *$} \\
\hline & Unemployed & 145.11 & 30.95 & \\
\hline \multirow[t]{4}{*}{ Years of diabetes } & $1-5$ & 152.92 & 35.17 & \multirow[t]{4}{*}{.652} \\
\hline & $6-10$ & 148.12 & 29.23 & \\
\hline & $11-20$ & 152.86 & 29.80 & \\
\hline & $>20$ & 147.33 & 32.52 & \\
\hline \multirow[t]{2}{*}{ Treatment regimen } & OADD & 152.37 & 42.27 & \multirow[t]{2}{*}{.365} \\
\hline & OADD + insulin & 147.36 & 29.52 & \\
\hline
\end{tabular}




\begin{tabular}{|l|l|l|l|l|}
\hline & Insulin alone & 154.83 & 26.43 & \\
\cline { 2 - 4 } & None & 147.00 & 67.88 \\
\hline \multirow{2}{*}{ Glycemic control (HbA1c) } & Optimal (<7\%) & 167.13 & 29.82 & $.000 *$ \\
\cline { 2 - 4 } & Non-optimal ( $\geq 7 \%)$ & 145.72 & 29.34 & \\
\hline
\end{tabular}

DSMS: Diabetes Self-Management Scale (60-240); BG: blood glucose; HbA1c: glycated hemoglobin A1c; OADD:oral antidiabetic drug; * statistically significant result $(\mathrm{p}<0.05)$; $\$$ post hoc analysis using Tukey's test showed a significant difference between the no education category and secondary $(\mathrm{p}=0.039)$ and university+ education ( $\mathrm{p}=0.001)$, as well as between middle-school and university+ education $(\mathrm{p}=0.005)$; ${ }^{1}$ according to the American Diabetes Association recommendation (American Diabetes Association (ADA), 2016);

Table 5:- Correlation between demographic and clinical factors with the diabetes self-management score subscales

\begin{tabular}{|c|c|c|c|c|c|c|c|c|c|c|c|c|c|c|c|}
\hline \multirow[t]{2}{*}{$\begin{array}{l}\text { Parame } \\
\text { ter }\end{array}$} & \multirow[t]{2}{*}{$\begin{array}{l}\text { Categor } \\
\mathbf{y}\end{array}$} & \multicolumn{2}{|c|}{$\begin{array}{l}\text { Healthy } \\
\text { eating }\end{array}$} & \multicolumn{2}{|c|}{$\begin{array}{l}\text { Being } \\
\text { active }\end{array}$} & \multicolumn{2}{|c|}{$\begin{array}{l}\text { Monitorin } \\
\text { g BG }\end{array}$} & \multicolumn{2}{|c|}{$\begin{array}{l}\text { Taking } \\
\text { medicatio } \\
\text { n }\end{array}$} & \multicolumn{2}{|c|}{ Foot care } & \multicolumn{2}{|c|}{$\begin{array}{l}\text { Problem } \\
\text { solving }\end{array}$} & \multicolumn{2}{|c|}{$\begin{array}{l}\text { Reducing } \\
\text { risk }\end{array}$} \\
\hline & & $\begin{array}{l}\mathrm{Me} \\
\text { an }\end{array}$ & SD & $\begin{array}{l}\text { Me } \\
\text { an }\end{array}$ & $\mathrm{SD}$ & $\begin{array}{l}\mathrm{Me} \\
\text { an }\end{array}$ & SD & $\begin{array}{l}\mathrm{Me} \\
\text { an }\end{array}$ & SD & $\begin{array}{l}\mathrm{Me} \\
\text { an }\end{array}$ & SD & $\begin{array}{l}\text { Me } \\
\text { an }\end{array}$ & SD & $\begin{array}{l}\mathrm{Me} \\
\text { an }\end{array}$ & SD \\
\hline \multirow[t]{4}{*}{ Sex } & Male & 2.4 & 0.6 & 2.1 & 0.8 & 2.2 & 0.7 & 2.5 & 0.7 & 2.6 & 0.7 & 2.6 & 0.6 & 2.6 & 0.6 \\
\hline & & 3 & 0 & 5 & 6 & 4 & 7 & 5 & 6 & 0 & 7 & 1 & 6 & 3 & 7 \\
\hline & Female & 2.5 & 0.6 & 2.0 & 0.8 & 2.1 & 0.7 & 2.5 & 0.7 & 2.5 & 0.7 & 2.5 & 0.6 & 2.6 & 0.6 \\
\hline & & 1 & 4 & 9 & 0 & 5 & 7 & 9 & 2 & 6 & 5 & 3 & 8 & 3 & 1 \\
\hline \multirow{10}{*}{$\begin{array}{l}\text { Age } \\
\text { (years) }\end{array}$} & $20-29$ & 2.5 & 0.5 & 2.2 & 0.8 & 2.2 & 0.7 & 2.5 & 0.8 & 2.6 & 0.8 & 2.7 & 0.6 & 2.6 & 0.7 \\
\hline & & 0 & 6 & 5 & $\mathbf{1}^{*}$ & 0 & $5^{*}$ & 7 & 5 & 8 & 3 & $\mathbf{0}$ & 9* & 8 & 1 \\
\hline & $30-39$ & 2.5 & 0.6 & 2.4 & 0.8 & 2.5 & 0.7 & 2.6 & 0.7 & 2.6 & 0.7 & 2.7 & 0.6 & 2.7 & 0.6 \\
\hline & & 8 & 2 & 0 & 6 & 1 & 7 & 3 & 4 & 5 & 4 & $\mathbf{0}$ & 6 & 5 & 5 \\
\hline & $40-49$ & 2.4 & 0.5 & 2.1 & 0.7 & 2.1 & 0.7 & 2.4 & 0.6 & 2.5 & 0.7 & 2.5 & 0.6 & 2.6 & 0.5 \\
\hline & & 9 & 8 & 1 & 6 & 8 & 1 & 8 & 6 & 5 & 1 & 7 & 4 & 1 & 7 \\
\hline & $50-59$ & 2.3 & 0.6 & 1.9 & 0.8 & 2.0 & 0.7 & 2.6 & 0.7 & 2.5 & 0.8 & 2.5 & 0.6 & 2.5 & 0.6 \\
\hline & & 5 & 5 & 7 & 7 & 8 & 9 & 6 & 7 & 8 & 3 & 2 & 9 & 5 & 7 \\
\hline & $\geq 60$ & 2.3 & 0.7 & 1.7 & 0.7 & 1.8 & 0.7 & 2.5 & 0.8 & 2.4 & 0.7 & 2.2 & 0.6 & 2.5 & 0.6 \\
\hline & & 7 & 1 & 6 & 5 & 6 & 6 & 2 & 6 & 4 & 7 & 7 & 6 & 6 & 9 \\
\hline \multirow{4}{*}{$\begin{array}{l}\text { Marital } \\
\text { status }\end{array}$} & Married & 2.4 & 0.6 & 1.9 & 0.8 & 2.0 & 0.7 & 2.6 & 0.7 & 2.5 & 0.7 & 2.5 & 0.6 & 2.6 & 0.6 \\
\hline & & 3 & 3 & 9 & 3 & 8 & 5 & 1 & 6 & 4 & 6 & $\mathbf{0}$ & 9 & 2 & 5 \\
\hline & Not & 2.5 & 0.6 & 2.3 & 0.7 & 2.4 & 0.7 & 2.5 & 0.7 & 2.6 & 0.7 & 2.7 & 0.6 & 2.6 & 0.6 \\
\hline & married & 4 & 0 & 8 & $7^{*}$ & 1 & $7^{\star}$ & 0 & 2 & 6 & 7 & $\mathbf{0}$ & $2 *$ & 4 & 3 \\
\hline \multirow{10}{*}{$\begin{array}{l}\text { Educatio } \\
\text { nal level }\end{array}$} & & 2.0 & 0.6 & 1.6 & 0.7 & 1.6 & 0.6 & 2.2 & 0.7 & 2.2 & 0.9 & 2.0 & 0.7 & 2.3 & 0.7 \\
\hline & $\begin{array}{l}\text { educatio } \\
\mathrm{n}\end{array}$ & 2 & $2^{+}$ & $\mathbf{0}$ & $2 *$ & 7 & 4 & 1 & 8 & 3 & $0^{+}$ & 6 & $1^{\dagger}$ & 2 & $3^{*}$ \\
\hline & Primary & 2.3 & 0.6 & 1.8 & 0.7 & 2.0 & 0.7 & 2.2 & 0.5 & 2.4 & 0.7 & 2.3 & 0.7 & 2.3 & 0.6 \\
\hline & & 2 & 4 & 8 & 8 & 1 & 8 & 7 & 2 & 5 & 2 & 9 & 2 & 5 & 7 \\
\hline & Middle- & 2.3 & 0.5 & 2.0 & 0.7 & 2.1 & 0.7 & 2.5 & 0.7 & 2.3 & 0.7 & 2.4 & 0.6 & 2.4 & 0.6 \\
\hline & school & $\mathbf{0}$ & 9 & $\mathbf{0}$ & 9 & 2 & 8 & 3 & 6 & 4 & $\mathbf{0}$ & $\mathbf{0}$ & 1 & 1 & 4 \\
\hline & Seconda & 2.5 & 0.5 & 2.1 & 0.8 & 2.1 & 0.7 & 2.5 & 0.6 & 2.5 & 0.7 & 2.6 & 0.6 & 2.6 & 0.5 \\
\hline & & 2 & 5 & 5 & 0 & 8 & 7 & 9 & 8 & 2 & 3 & 1 & 1 & 8 & 7 \\
\hline & Universi & 2.6 & 0.6 & 2.3 & 0.8 & 2.4 & 0.7 & 2.6 & 0.7 & 2.8 & 0.7 & 2.7 & 0.6 & 2.7 & 0.6 \\
\hline & ty+ & 3 & 3 & 0 & 6 & $\mathbf{0}$ & 4 & 4 & 9 & 4 & 3 & 7 & 7 & 8 & 3 \\
\hline \multirow{4}{*}{$\begin{array}{l}\text { Professi } \\
\text { onal } \\
\text { status }\end{array}$} & Employ & 2.5 & 0.6 & 2.2 & 0.8 & 2.3 & 0.7 & 2.6 & 0.6 & 2.6 & 0.7 & 2.6 & 0.6 & 2.6 & 0.6 \\
\hline & & 2 & 1 & 3 & 1 & 1 & 1 & 3 & 9 & 3 & 2 & 7 & 3 & 8 & 0 \\
\hline & & 2.4 & 0.6 & 1.9 & 0.8 & 2.0 & 0.8 & 2.4 & 0.8 & 2.5 & 0.8 & 2.4 & 0.7 & 2.5 & 0.6 \\
\hline & $\begin{array}{l}\text { employe } \\
\text { d }\end{array}$ & 0 & 2 & 8 & $3 *$ & 4 & 0* & 6 & 0 & 1 & 1 & 4 & 0* & 6 & 7 \\
\hline \multirow{5}{*}{$\begin{array}{l}\text { Years of } \\
\text { diabetes }\end{array}$} & $1-5$ & 2.6 & 0.6 & 2.3 & 0.8 & 2.2 & 0.8 & 2.4 & 0.9 & 2.7 & 0.8 & 2.7 & 0.7 & 2.6 & 0.7 \\
\hline & & 0 & 9 & 0 & 9* & 2 & 0 & 8 & 1 & 5 & 1 & 0 & 2 & 8 & 1 \\
\hline & $6-10$ & 2.4 & 0.5 & 2.1 & 0.8 & 2.1 & 0.7 & 2.5 & 0.6 & 2.4 & 0.7 & 2.5 & 0.6 & 2.6 & 0.6 \\
\hline & & 1 & 4 & 1 & 1 & 8 & 4 & 4 & 8 & 7 & 2 & 2 & 3 & 1 & 3 \\
\hline & $11-20$ & 2.4 & 0.6 & 2.1 & 0.8 & 2.2 & 0.7 & 2.6 & 0.7 & 2.6 & 0.7 & 2.6 & 0.6 & 2.6 & 0.5 \\
\hline
\end{tabular}




\begin{tabular}{|c|c|c|c|c|c|c|c|c|c|c|c|c|c|c|c|}
\hline & & 9 & 2 & 5 & 3 & 8 & 8 & 0 & 0 & 0 & 2 & 0 & 7 & 3 & 7 \\
\hline & $>20$ & $\begin{array}{l}2.3 \\
5 \\
\end{array}$ & $\begin{array}{l}0.7 \\
4\end{array}$ & $\begin{array}{l}1.6 \\
8\end{array}$ & $\begin{array}{l}0.6 \\
7\end{array}$ & $\begin{array}{l}1.9 \\
4\end{array}$ & $\begin{array}{l}0.7 \\
6\end{array}$ & $\begin{array}{l}2.6 \\
9 \\
\end{array}$ & $\begin{array}{l}0.8 \\
8\end{array}$ & $\begin{array}{l}2.6 \\
0\end{array}$ & $\begin{array}{l}0.8 \\
9\end{array}$ & $\begin{array}{l}2.4 \\
1\end{array}$ & $\begin{array}{l}0.7 \\
0\end{array}$ & $\begin{array}{l}2.5 \\
6\end{array}$ & $\begin{array}{l}0.7 \\
5\end{array}$ \\
\hline \multirow{4}{*}{$\begin{array}{l}\text { Treatme } \\
\text { nt } \\
\text { regimen }\end{array}$} & OADD & $\begin{array}{l}2.4 \\
9 \\
\end{array}$ & $\begin{array}{l}0.6 \\
7 \\
\end{array}$ & $\begin{array}{l}2.1 \\
3 \\
\end{array}$ & $\begin{array}{l}\mathbf{0 . 9} \\
0 *\end{array}$ & $\begin{array}{l}2.0 \\
7 \\
\end{array}$ & $\begin{array}{l}\mathbf{0 . 8} \\
0^{*}\end{array}$ & $\begin{array}{l}1.9 \\
7\end{array}$ & $\begin{array}{l}1.0 \\
5^{\star}\end{array}$ & $\begin{array}{l}2.5 \\
1 \\
\end{array}$ & $\begin{array}{l}0.8 \\
5 \\
\end{array}$ & $\begin{array}{l}2.4 \\
8 \\
\end{array}$ & $\begin{array}{l}0.7 \\
3 *\end{array}$ & $\begin{array}{l}2.6 \\
2 \\
\end{array}$ & $\begin{array}{l}0.7 \\
0 \\
\end{array}$ \\
\hline & $\begin{array}{l}\text { OADD } \\
+ \text { insulin }\end{array}$ & $\begin{array}{l}2.4 \\
0 \\
\end{array}$ & $\begin{array}{l}0.6 \\
0\end{array}$ & $\begin{array}{l}1.9 \\
8\end{array}$ & $\begin{array}{l}0.7 \\
9\end{array}$ & $\begin{array}{l}2.1 \\
9 \\
\end{array}$ & $\begin{array}{l}0.7 \\
7\end{array}$ & $\begin{array}{l}2.6 \\
5\end{array}$ & $\begin{array}{l}.6 \\
8\end{array}$ & $\begin{array}{l}2.5 \\
9 \\
\end{array}$ & $\begin{array}{l}0.7 \\
1\end{array}$ & $\begin{array}{l}2.5 \\
5\end{array}$ & $\begin{array}{l}0.6 \\
3\end{array}$ & $\begin{array}{l}2.6 \\
3 \\
\end{array}$ & $\begin{array}{l}0.6 \\
2 \\
\end{array}$ \\
\hline & $\begin{array}{l}\text { Insulin } \\
\text { alone }\end{array}$ & $\begin{array}{l}2.5 \\
4 \\
\end{array}$ & $\begin{array}{l}0.5 \\
1 \\
\end{array}$ & $\begin{array}{l}2.3 \\
0\end{array}$ & $\begin{array}{l}0.6 \\
9 \\
\end{array}$ & $\begin{array}{l}2.3 \\
9 \\
\end{array}$ & $\begin{array}{l}0.6 \\
6 \\
\end{array}$ & $\begin{array}{l}2.6 \\
7 \\
\end{array}$ & $\begin{array}{l}0.5 \\
9 \\
\end{array}$ & $\begin{array}{l}2.6 \\
3 \\
\end{array}$ & $\begin{array}{l}0.6 \\
9 \\
\end{array}$ & $\begin{array}{l}2.7 \\
5 \\
\end{array}$ & $\begin{array}{l}0.5 \\
6 \\
\end{array}$ & $\begin{array}{l}2.6 \\
5 \\
\end{array}$ & $\begin{array}{l}0.5 \\
4 \\
\end{array}$ \\
\hline & None & $\begin{array}{l}2.5 \\
9\end{array}$ & $\begin{array}{l}1.0 \\
2\end{array}$ & $\begin{array}{l}2.4 \\
8\end{array}$ & $\begin{array}{l}1.2 \\
6\end{array}$ & $\begin{array}{l}2.2 \\
0 \\
\end{array}$ & $\begin{array}{l}1.0 \\
3 \\
\end{array}$ & $\begin{array}{l}2.1 \\
7\end{array}$ & $\begin{array}{l}1.6 \\
5\end{array}$ & $\begin{array}{l}2.9 \\
1 \\
\end{array}$ & $\begin{array}{l}0.9 \\
3 \\
\end{array}$ & $\begin{array}{l}2.5 \\
3 \\
\end{array}$ & $\begin{array}{l}1.0 \\
4\end{array}$ & $\begin{array}{l}2.6 \\
2\end{array}$ & $\begin{array}{l}0.9 \\
6 \\
\end{array}$ \\
\hline \multirow[t]{2}{*}{$\begin{array}{l}\text { Glycemi } \\
\text { c control }\end{array}$} & Optimal & $\begin{array}{l}2.7 \\
1 \\
\end{array}$ & $\begin{array}{l}0.7 \\
1 \\
\end{array}$ & $\begin{array}{l}2.3 \\
9 \\
\end{array}$ & $\begin{array}{l}0.8 \\
6 \\
\end{array}$ & $\begin{array}{l}2.4 \\
0 \\
\end{array}$ & $\begin{array}{l}0.7 \\
7 \\
\end{array}$ & $\begin{array}{l}2.7 \\
8 \\
\end{array}$ & $\begin{array}{l}0.7 \\
6 \\
\end{array}$ & $\begin{array}{l}2.7 \\
9 \\
\end{array}$ & $\begin{array}{l}0.7 \\
6 \\
\end{array}$ & $\begin{array}{l}2.7 \\
1 \\
\end{array}$ & $\begin{array}{l}0.6 \\
6 \\
\end{array}$ & $\begin{array}{l}2.7 \\
7 \\
\end{array}$ & $\begin{array}{l}0.6 \\
0\end{array}$ \\
\hline & $\begin{array}{l}\text { Non- } \\
\text { optimal }\end{array}$ & $\begin{array}{l}2.3 \\
8 \\
\end{array}$ & $\begin{array}{l}0.5 \\
7 \\
\end{array}$ & $\begin{array}{l}2.0 \\
2 \\
\end{array}$ & $\begin{array}{l}0.8 \\
0^{+}\end{array}$ & $\begin{array}{l}2.1 \\
2 \\
\end{array}$ & $\begin{array}{l}0.7 \\
6^{*}\end{array}$ & $\begin{array}{l}2.5 \\
1 \\
\end{array}$ & $\begin{array}{l}\mathbf{0 . 7} \\
3^{*}\end{array}$ & $\begin{array}{l}2.5 \\
1 \\
\end{array}$ & $\begin{array}{l}0.7 \\
5^{*} \\
\end{array}$ & $\begin{array}{l}2.5 \\
2 \\
\end{array}$ & $\begin{array}{l}\mathbf{0 . 6} \\
7 * \\
\end{array}$ & $\begin{array}{l}2.5 \\
8 \\
\end{array}$ & $\begin{array}{l}0.6 \\
5^{*}\end{array}$ \\
\hline
\end{tabular}

BG: blood glucose; ADD: oral antidiabetic drug; statistically significant results are marked in bold characters; significance level: $* \mathrm{p}<0.05$, $\$ \mathrm{p}<0.001$; otherwise, results are not statistically significant.

Table 6:- Demographic and clinical parameters and diabetes self-management as predictors for glycemic control (binary logistic regression)

\begin{tabular}{|c|c|c|c|c|c|c|c|c|c|}
\hline \multirow{4}{*}{$\begin{array}{l}\text { Predictor } \\
\text { Sex }\end{array}$} & \multirow{3}{*}{$\begin{array}{l}\text { Category } \\
\text { Male }(r e f) \\
\end{array}$} & \multicolumn{4}{|c|}{ Univariate model } & \multicolumn{4}{|c|}{ Multivariate model } \\
\hline & & \multirow{2}{*}{$\begin{array}{l}\text { OR } \\
- \\
\end{array}$} & \multicolumn{2}{|c|}{$95 \% \mathrm{CI}$} & \multirow{2}{*}{$\begin{array}{l}\text { p- } \\
\text { value } \\
- \\
\end{array}$} & \multirow{2}{*}{$\begin{array}{l}\text { OR } \\
N I \\
\end{array}$} & \multicolumn{2}{|c|}{$95 \%$ CI } & \multirow{2}{*}{$\begin{array}{l}\text { p- } \\
\text { value } \\
N I \\
\end{array}$} \\
\hline & & & - & - & & & $N I$ & $N I$ & \\
\hline & Female & 1.04 & 0.65 & 1.68 & .857 & $N I$ & $N I$ & NI & $N I$ \\
\hline \multirow[t]{5}{*}{ Age (years) } & $20-29$ (ref) & - & - & - & .197 & - & - & - & .606 \\
\hline & $30-39$ & 0.87 & 0.39 & 1.95 & .742 & 0.68 & 0.18 & 2.52 & .563 \\
\hline & $40-49$ & 0.62 & 0.29 & 1.34 & .224 & 0.50 & 0.14 & 1.75 & .279 \\
\hline & $50-59$ & 0.62 & 0.27 & 1.42 & .259 & 0.43 & 0.11 & 1.70 & .227 \\
\hline & $\geq 60$ & 0.28 & 0.09 & 0.89 & $.030 *$ & 0.18 & 0.01 & 2.19 & .176 \\
\hline \multirow[t]{2}{*}{ Marital status } & $\operatorname{Married}(r e f)$ & - & - & - & - & $N I$ & $N I$ & $N I$ & $N I$ \\
\hline & Not married & 1.04 & 0.63 & 1.72 & .869 & $N I$ & $N I$ & $N I$ & $N I$ \\
\hline \multirow[t]{5}{*}{ Educational level } & $\begin{array}{ll}\text { No } & \text { education } \\
(\text { ref })\end{array}$ & - & - & - & .097 & $N C$ & $N C$ & $N C$ & .947 \\
\hline & Primary & 1.26 & 0.23 & 6.98 & .789 & $N C$ & $N C$ & $N C$ & 1.000 \\
\hline & Middle-school & 2.05 & 0.52 & 8.06 & .306 & $N C$ & $N C$ & $N C$ & .998 \\
\hline & Secondary & 2.67 & 0.75 & 9.45 & .129 & $N C$ & $N C$ & $N C$ & .998 \\
\hline & University+ & 3.80 & 1.08 & 13.40 & $.038^{*}$ & $N C$ & $N C$ & $N C$ & .998 \\
\hline \multirow[t]{2}{*}{ Professional status } & Employed(ref) & - & - & - & - & $N I$ & $N I$ & $N I$ & $N I$ \\
\hline & Not employed & 0.70 & 0.43 & 1.14 & .148 & $N I$ & $N I$ & $N I$ & $N I$ \\
\hline \multirow[t]{4}{*}{ Years of diabetes } & $1-5(r e f)$ & - & - & - & .058 & - & - & - & .328 \\
\hline & $6-10$ & 0.51 & 0.27 & .96 & $.037 *$ & 0.96 & 0.28 & 3.24 & .942 \\
\hline & $11-20$ & 0.86 & 0.46 & 1.61 & .631 & 2.12 & 0.59 & 7.68 & .251 \\
\hline & $>20$ & 0.34 & 0.12 & 1.00 & .050 & 1.48 & 0.26 & 8.41 & .660 \\
\hline \multirow[t]{4}{*}{ Treatment regimen } & None (ref) & - & - & - & $.000 *$ & - & - & - & .312 \\
\hline & OADD & 0.50 & 0.14 & 1.73 & .274 & 0.93 & 0.02 & 35.46 & .967 \\
\hline & Insulin alone & 0.18 & 0.05 & 0.68 & $.011^{*}$ & 0.27 & 0.01 & 10.12 & .479 \\
\hline & OADD + insulin & 0.19 & 0.05 & 0.65 & $.009 *$ & 0.33 & 0.01 & 12.24 & .546 \\
\hline \multirow{4}{*}{$\begin{array}{lr}\begin{array}{l}\text { Quality of } \\
\text { management } \\
\text { level) }\end{array} & \begin{array}{r}\text { self- } \\
\text { (DSMS }\end{array} \\
& \end{array}$} & Poor $(<133)($ ref $)$ & - & - & - & $.000^{*}$ & - & - & - & .747 \\
\hline & $\begin{array}{l}\text { Moderate (133 - } \\
150)\end{array}$ & 2.46 & 0.80 & 7.58 & .116 & 1.77 & 0.35 & 8.88 & .488 \\
\hline & $\begin{array}{l}\text { Good } \quad(150 \quad- \\
170)\end{array}$ & 2.07 & .67 & 6.46 & .208 & 2.48 & 0.21 & 10.39 & .692 \\
\hline & Excellent $(\geq 170)$ & 8.17 & 2.89 & 23.14 & $.000^{*}$ & 3.01 & 0.21 & 42.98 & .416 \\
\hline
\end{tabular}




\begin{tabular}{|l|l|l|l|l|l|l|l|l|l|}
\hline Healthy eating & (Raw score) & 1.06 & 1.03 & 1.09 & $.000^{*}$ & 1.03 & 0.96 & 1.10 & .411 \\
\hline Being active & (Raw score) & 1.10 & 1.04 & 1.15 & $.000^{*}$ & 1.02 & 0.92 & 1.13 & .685 \\
\hline Monitoring BG & (Raw score) & 1.10 & 1.03 & 1.17 & $.003^{*}$ & 1.06 & 0.91 & 1.22 & .470 \\
\hline Taking medication & (Raw score) & 1.09 & 1.01 & 1.17 & $.021^{*}$ & 1.05 & 0.93 & 1.17 & .443 \\
\hline Foot care & (Raw score) & 1.08 & 1.03 & 1.13 & $.002^{*}$ & 1.06 & 0.94 & 1.20 & .307 \\
\hline Reducing risk & (Raw score) & 1.04 & 1.01 & 1.07 & $.012^{*}$ & 0.95 & 0.88 & 1.03 & .183 \\
\hline Problem solving & (Raw score) & 1.06 & 1.01 & 1.11 & $.018^{*}$ & 0.96 & 0.85 & 1.09 & .552 \\
\hline
\end{tabular}

Dependent variable $=$ optimal glycemic control defined as $\mathrm{HbAlc}<7 \%$ (predicted value $=$ yes; binomial variable); Ref: predictor category used as reference to calculate the regression coefficients; * statistically significant result $(\mathrm{p}<0.05) ; N I$ : variable not included in the model; $N C$ : value not calculable; DSMS: Diabetes Self-Management Scale; OADD: oral anti diabetic drug

Figure 1:- Correlation between HbA1C levels and diabetes self-management scale (DSM) score.

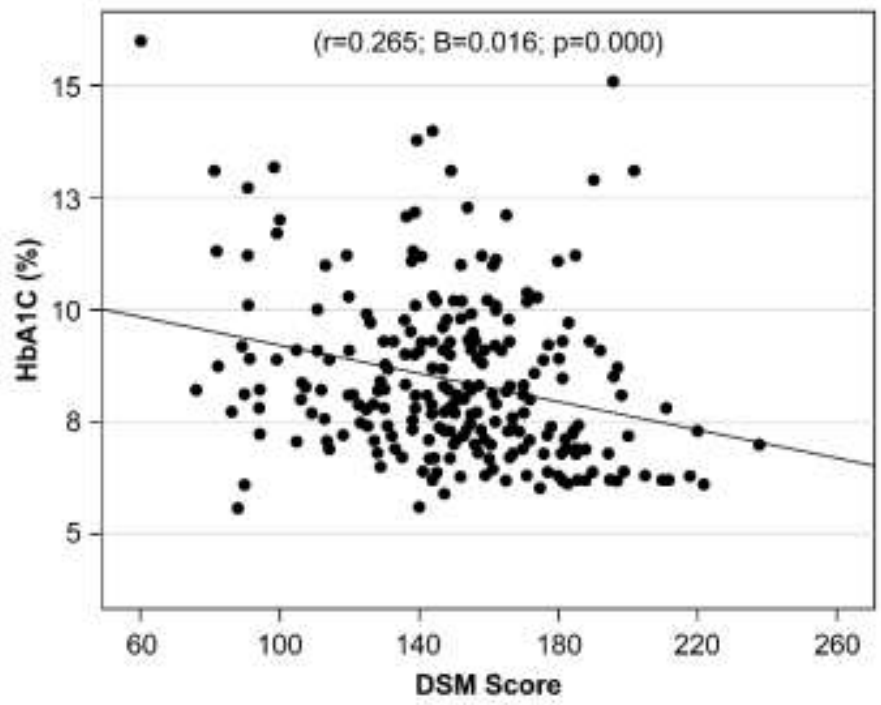

Linear regression showed a weak but significant negative correlation between HbAlc (\%) and the Diabetes SelfManagement Scale (DSMS) score $(\mathrm{r}=0.265 ; \mathrm{B}=0.016 ; \mathrm{p} \leq .001 *)$. Analysis used the DSMS raw value $(60-240)$ as the independent variable and $\mathrm{HbA} 1 \mathrm{c}$ level as the dependent variable.

Figure 2:- Correlation between diabetes self-management and glycemic control

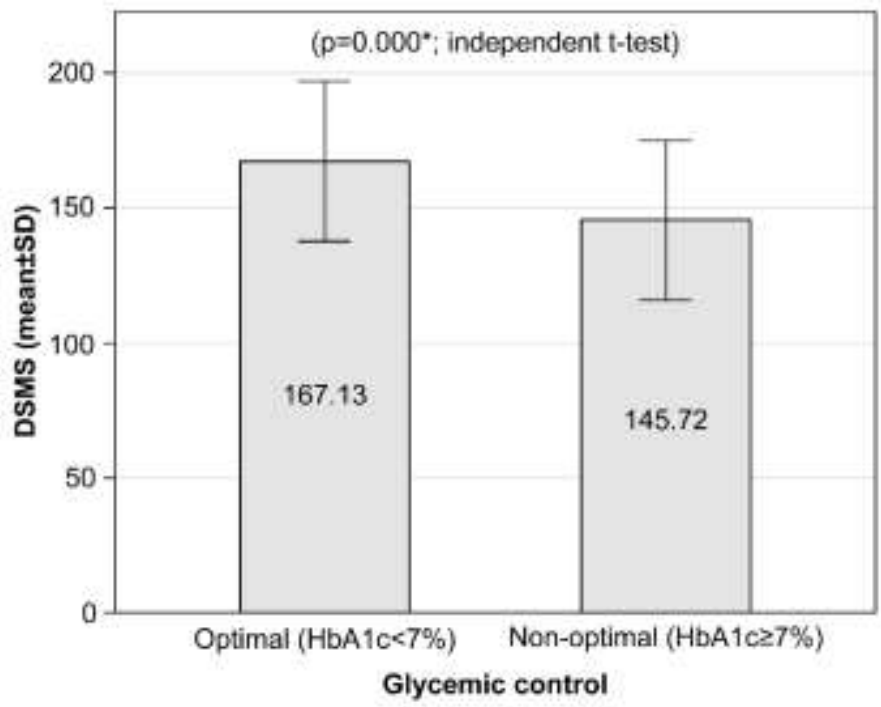

Bars represent the mean diabetes self-management scale score in the group of patients with optimal glycemic control versus those with unsatisfactory glycemic control. 


\section{References:-}

1. Robert AA, Al Dawish MA, Braham R, Musallam MA, Al Hayek AA and Al Kahtany NH. Type 2 Diabetes Mellitus in Saudi Arabia: Major Challenges and Possible Solutions. Curr Diabetes Rev2017;13:59-64.

2. Alqurashi KA, Aljabri KS andBokhari SA. Prevalence of diabetes mellitus in a Saudi community. Ann Saudi Med 2011; 31: 19-23.

3. Alhowaish A. Economic costs of diabetes in Saudi Arabia. J Fam Community Med 2013;20: 1.

4. Buyken AE, von Eckardstein A, Schulte H, Cullen P andAssmann G. Type 2 diabetes mellitus and risk of coronary heart disease: results of the 10-year follow-up of the PROCAM study. Eur J Cardiovasc PrevRehabil 2007; 14: 230-236.

5. Cade WT. Diabetes-related microvascular and macrovascular diseases in the physical therapy setting. Phys Ther 2008;88: 1322-1335.

6. Al Slail FY,Abid O, Assiri AM, Memish ZA and Ali MK. Cardiovascular risk profiles of adults with type-2 diabetes treated at urban hospitals in Riyadh, Saudi Arabia. J Epidemiol Glob Health 2016; 6: 29-36.

7. Al Dawish MA, Robert AA, Braham R, Al Hayek AA, Al Saeed A, Ahmed R and Al Sabaan FS. Diabetes mellitus in Saudi Arabia: a review of the recent literature. Curr Diabetes Rev 2016;12: 359-368.

8. American Diabetes Association (ADA). Standards of Medical Care in Diabetes-2016 Abridged for Primary Care Providers. Clin Diabetes 2016; 34: 3-21.

9. Senitan M, Alhaiti AH, Gillespie J, Alotaibi BF andLenon GB. The Referral System between Primary and Secondary Health Care in Saudi Arabia for Patients with Type 2 Diabetes: A Systematic Review. J Diabetes Res2017;2017: 4183604.

10. Abahussain NA and El-Zubier AG. Diabetes knowledge among self reported diabetic female teachers: Alkhobar, Saudi Arabia. J Family Community Med 2005; 12: 43-48.

11. Karim A, Ogbeide DO, Siddiqui S and Al-Khalifa IM. Prevalence of diabetes mellitus in a Saudi community. Saudi Med J 2000; 21: 438-442.

12. Al-Ghamdi AJ, Al-Turki KA, Al-Baghli NA and El-Zubaier AG. A community-based screening campaign for the detection of diabetes mellitus and hypertension in the eastern province, saudiarabia: methods and participation rates. J Family Community Med 2007; 14: 91-97.

13. Abou-Gamel M, Jabri G, Alsharif A, Al-Rehaili R, Al-Gabban A, Alshabi Y, Gamel RA and Hodhiri A. Level of Glycemic Control and Barriers of Good Compliance among Diabetic Patients in Al-Madina, Kingdom of Saudi Arabia. Br J Med Res 2015;5: 819.

14. Al-Rasheedi AA. Glycemic control among patients with type 2 diabetes mellitus in countries of Arabic Gulf. Int J Health Sci (Qassim) 2015;9: 345.

15. Badedi M, Solan Y, Darraj H, Sabai A, Mahfouz M, Alamodi S,Alsabaani A. Factors Associated with LongTerm Control of Type 2 Diabetes Mellitus. J Diabetes Res 2016;2016: 2109542.

16. Almutairi MA, Said SM andZainuddin H. Predictors of poor glycemic control among type two diabetic patients. Am J Med Sci 2013; 3: 17-21.

17. Spellman CW. Achieving glycemic control: cornerstone in the treatment of patients with multiple metabolic risk factors. J Am Osteopath Assoc 2009;109: S8.

18. Stettler C, Allemann S, Jüni P, Cull CA, Holman RR, Egger M, Krähenbühl S and Diem P. Glycemic control and macrovascular disease in types 1 and 2 diabetes mellitus: Meta-analysis of randomized trials. Am Heart $\mathbf{J}$ 2006; 152: 27-38.

19. Aljabri KS andBokhari SA. Glycemic control of patients with type 1 diabetes mellitus in Saudi community. J Diabetes Metab 2013; $4: 4$.

20. Alsulaiman TA, Al-Ajmi HA, Al-Qahtani SM, Fadlallah IM, Nawar NE, Shukerallah RE, Nadeem SR, AlWeheedy NM, Al-Sulaiman KA, Hassan AA, Shahin AA and Kolib TM. Control of type 2 diabetes in King Abdulaziz Housing City (Iskan) population, Saudi Arabia. J Family Community Med 2016;23: 1.

21. Munshi MN, Segal AR, Suhl E, Ryan C, Sternthal A, Giusti J, Lee Y, Fitzgerald S, Staum E, Bonsignor P, DesRochersL, McCartney R and Weinger K. Assessment of barriers to improve diabetes management in older adults: a randomized controlled study. Diabetes Care 2013; 36: 543-549.

22. Kakade AA, Mohanty IR and Rai S. Assessment of knowledge, attitude and self-care activities among type-2 diabetic patients attending a tertiary care teaching hospital. Int J Basic ClinPharmacol 2016; 5: 2458-2462.

23. Daly JM, Hartz AJ, Xu Y, Levy BT, James PA, Merchant ML and Garrett RE. An assessment of attitudes, behaviors, and outcomes of patients with type 2 diabetes. J Am Board Fam Med 2009; 22: 280-290.

24. Musenge EM, Michelo C, Mudenda B andManankov A. Glycaemic Control and Associated Self-Management Behaviours in Diabetic Outpatients: A Hospital Based Observation Study in Lusaka, Zambia. J DiabetesRes 2015;2016: 7934654 
25. Houle J, Lauzier-Jobin F, Beaulieu M-D, Meunier S, Coulombe S, Côté J, Lesperance F, Chiasson JL, Bherer L and Lambert J. Socioeconomic status and glycemic control in adult patients with type 2 diabetes: a mediation analysis. BMJ Open Diabetes Res Care 2016;4: e000184.

26. McBrien KA, Naugler C, Ivers N, Weaver RG, Campbell D,Desveaux L, Hemmelgarn BR, Edwards AL, Saad N, Nicholas D and Manns BJ. Barriers to care in patients with diabetes and poor glycemic control - A crosssectional survey. PLoS One 2017;12: e0176135.

27. Powers MA, Bardsley J, Cypress M, Duker P, Funnell MM, Fischl AH, Maryniuk MD, Siminerio L and Vivian E. Diabetes Self-management Education and Support in Type 2 Diabetes. Diabetes Educ 2017; 43: 40-53.

28. Walker C, Swerissen H and Belfrage J. Self-management: its place in the management of chronic illnesses. Aust Health Rev 2003; 26: 34-42.

29. Funnell MM, Brown TL, Childs BP, Haas LB, Hosey GM, Jensen B, Maryniuk M, Peyrot M, Piette JD, Reader D, Siminerio LM, Weinger K and Weiss MA. National Standards for Diabetes Self-Management Education. Diabetes Care 2009; 32: S87-94.

30. Sousa VD, Zauszniewski JA, Musil CM, Lea PJP and Davis SA. Relationships among self-care agency, selfefficacy, self-care, and glycemic control. Res Theory NursPract 2005;19: 217.

31. Al-Khawaldeh OA, Al-Hassan MA andFroelicher ES. Self-efficacy, self-management, and glycemic control in adults with type 2 diabetes mellitus. J Diabetes Complications 2012; 26: 10-16.

32. Al-Qazaz HK, Sulaiman SA, Hassali MA, Shafie AA, Sundram S, Al-Nuri R and Saleem F. Diabetes knowledge, medication adherence and glycemic control among patients with type 2 diabetes. Int J Clin Pharm 2011; 33: 1028-1035.

33. Saucier AN, Ansa B, Coffin J, Akhtar M, Miller A, Mahoney H, Hodo DM, Duffie C, Fontenot B, Andrews HE and Smith SA. Patient perspectives of an individualized diabetes care management plan. Eur J Pers Cent Healthc 2017; 5: 213-219.

34. Yusuff KB, Obe $\mathrm{O}$ and Joseph BY. Adherence to anti-diabetic drug therapy and self management practices among type-2 diabetics in Nigeria. Pharm World Sci 2008; 30: 876-883.

35. Fisher L, Polonsky WH, Parkin CG, Jelsovsky Z, Petersen B and Wagner RS. The impact of structured blood glucose testing on attitudes toward self-management among poorly controlled, insulin-naïve patients with type 2 diabetes. DiabetesRes Clin Pract 2012; 96: 149-155.

36. Nie L, Xie B, Yang Y and Shan YM. Characteristics of Chinese m-Health Applications for Diabetes SelfManagement. Telemed J E Health 2016; 22: 614-619.

37. Schmitt A, Gahr A, Hermanns N, Kulzer B, Huber J andHaak T. The Diabetes Self-Management Questionnaire (DSMQ): development and evaluation of an instrument to assess diabetes self-care activities associated with glycaemic control. Health Qual Life Outcomes 2013; 11: 138.

38. Elgart JF, González L, Rucci E andGagliardino JJ. Self-monitoring of blood glucose: use, frequency drivers, and cost in Argentina. J Diabetes Sci Technol 2014; 8: 1121-1125.

39. Sousa VD, Hartman SW, Miller EH and Carroll MA. New measures of diabetes self-care agency, diabetes selfefficacy, and diabetes self-management for insulin-treated individuals with type 2 diabetes. J ClinNurs 2009; 18: 1305-1312.

40. Ontario HQ. Behavioural Interventions for Type 2 Diabetes: An Evidence-Based Analysis. Ont Health Technol Assess Ser 2009; 9: 1-45.

41. American Diabetes Association. Standards of Medical Care in Diabetes--2014. Diabetes Care 2014; 37: S14-80.

42. Turner RC. Glycemic Control With Diet, Sulfonylurea, Metformin, or Insulin in Patients With Type 2 Diabetes Mellitus: Progressive Requirement for Multiple Therapies (UKPDS 49). UK Prospective Diabetes Study (UKPDS) Group. JAMA 1999; 281: 2005.

43. Khattab M, Khader YS, Al-Khawaldeh A andAjlouni K. Factors associated with poor glycemic control among patients with Type 2 diabetes. J Diabetes Complications 2010; 24: 84-89.

44. Mahmood MI, Daud F and Ismail A. Glycaemic control and associated factors among patients with diabetes at public health clinics in Johor, Malaysia. Public Health 2016; 135: 56-65.

45. Mwavua SM, Ndungu EK, Mutai KK and Joshi MD. A comparative study of the quality of care and glycemic control among ambulatory type 2 diabetes mellitus clients, at a Tertiary Referral Hospital and a Regional Hospital in Central Kenya. BMC Res Notes 2016;9: 12.

46. Cheng L, Leung DY, Sit JW, Li X, Wu Y, Yang M, Gao CX and Hui R. Factors associated with diet barriers in patients with poorly controlled type 2 diabetes. Patient Prefer Adherence 2016;10:37.

47. Almutairi KM. Quality of Diabetes Management in Saudi Arabia: A Review of Existing Barriers. Arch Iran Med 2015; 18: 816-821.

48. Heisler M, Cole I, Weir D, Kerr EA and Hayward RA. Does physician communication influence older patients' 
diabetes self-management and glycemic control? Results from the Health and Retirement Study (HRS). Journals Gerontol Ser A Biol Sci Med Sci 2007;62: 1435-1442.

49. Tavakol M andDennick R. Making sense of Cronbach's alpha. Int J Med Educ 2011; 2: 53-55.

50. Glasgow RE, Hampson SE, Strycker LA and Ruggiero L. Personal-Model Beliefs and Social-Environmental Barriers Related to Diabetes Self-Management. Diabetes Care 1997; 20: 556-561.

51. Glasgow RE and Anderson RM. In diabetes care, moving from compliance to adherence is not enough. Something entirely different is needed. Diabetes Care 1999; 22: 2090-2092.

52. Cheng AY. Canadian Diabetes Association Clinical Practice Guidelines Expert Committee: Canadian diabetes association 2013 clinical practice guidelines for the prevention and management of diabetes in Canada. Can J Diabetes 2013; 37: S1-S212. 